\title{
Public Health and Genetic Constitution of the San ("Bushmen"): Carbohydrate Metabolism and Acetylator Status of the !Kung* of Tsumkwe in the North-western Kalahari
}

\author{
TREFOR JENKINS， H. LEHMANN， G. T. NURSE
}

It therefore seemed advisable to us to incorporate into our ongoing study of the peoples of South West Africa an investigation of lactose tolerance in a San group and to try to

Summary

Intolerance to lactose owing to deficiency of lactase is particularly prevalent among non-Caucasian peoples. Special caution is therefore needed in offering them milk supplements. Lactose tolerance has been investigated among the !Kung in the north-western Kalahari. The opportunity was taken also to examine their acetylator status, as this affects their ability to detoxicate drugs given for the treatment of tuberculosis and other diseases.

The preliminary studies reported here suggest that not more than $10 \%$ of the !Kung are tolerant to lactose, but only one person out of 30 was a slow acetylator.

\section{Introduction}

It has been recognized for many years in Uganda (Dean, 1962) and South Africa (Bowie et al., 1963) that milk supplements should be given with caution to Negro patients. In 1965 Cuatrecasas et al. described lactase deficiency in adults and Bayless and Rosensweig (1966) established that the deficiency was significantly more prevalent in American Negroes than in American whites. Cook and Kajubi (1966) showed that in Africa a similar contrast existed between non-pastoral "Bantu" (Negroes) and pastoral "Hamites" (Caucasians). By 1970 it had begun to appear that lactose tolerance rather than intolerance represented the variant type and was virtually confined to Caucasians of North-Western Europe and America and a few pastoral peoples (Simoons, 1970).

The fact that a high prevalence of lactose intolerance may vitiate the effectiveness of nutritional programmes in which large quantities of milk powder are distributed to nonCausasian peoples has been pointed out by Kretschmer (1972). The San (Bushmen) of the Kalahari have not until recently possessed cattle and have never, so far as is known, been consumers of milk. Furthermore, a recent paper by Joffe et al. (1971) has shown that they are relatively intolerant to glucose and that stress or unusual or inadequate nutrition does not seem to account completely for their abnormalities of carbohydrate metabolism. Some of the San are beginning to assume a cash economy and the ready availability of refined sugar and its products might therefore pose a threat to their wellbeing. They are also becoming exposed to a wider variety of infectious diseases than they might be expected to be able to resist and tuberculosis, in particular, afflicts them seriously and often.

"! indicates a "click" sound.

Human Serogenetics Unit, School of Pathology, South African Institute for Medical Research and University of the Witwatersrand, Johannesburg

TREFOR JENKINS, M.D., Head of Unit

G. T. NURSE, M.B., D.P.H., Haematologist

Biochemistry Department, University of Cambridge, Cambridge CB2 20R

H. LEHMANN, F.R.C.P., F.R.S., Professor of Clinical Biochemistry confirm or refute the findings of Joffe at al. A genetic polymorphism of isoniazid metabolism has been shown to exist (Knight et al. 1959) and to control acetylation (Evans, 1962). The acetylation of sulphadimidine is under the same genetic control as isoniazid (Peters et al. 1965). Since isoniazid is widely used in the treatment of tuberculosis and sulphonamides are among the medicaments supplied to the clinics which the San periodically attend the determination of acetylator status also seemed to be indicated, as this would have a bearing on the ability to detoxicate the drugs, and consequently on the dosage which patients ought to receive. We should here like to emphasize our view that anthropological studies should be of use to the people on whom they are done.

\section{Methods}

\section{POPULATION}

The !Kung of Bushmanland of the north-western Kalahari are members of the largest remaining single division of the San. What is substantially the same people extends under a variety of local names from north-western Botswana across the north-eastern part of South West Africa into the Huila, Cuanda-Cubango, and Moxico districts of southern Angloa (Guerreiro, 1968; fig. 1). The northern, Angola, group numbers about 4,000, the central group consists of about 7,000 individuals and extends from the western margin of the Okavango Swamp in Botswana to the farms of the Grootfontein district in South West Africa, while the small southern group of about 2,000 people is found on the farms of the Gobabis district in South West Africa and the Ghanzi district in Botswana (Lee, 1965). All speak mutually intelligible dialeots of Northern Bushman (Westphal, 1963). The ! Kung of Bushmanland have until recently been a hunter-gatherer folk (Thomas, 1959) to a certain extent they still are. This means that they depend traditionally for their foodstuffs on animals and birds hunted by the men and boys and on a variety of wild indigenous plants (veldkos) gathered by the women.

\section{SAMPLES}

The samples consisted of all the healthy adult volunteers we could assemble at Tsumkwe (fig. 1), the administrative centre of Busmanland, and persuade to undergo the tests. Fonty people were tested for lactose tolerance and six underwent glucose tolerance tests. All those in the glucose tolerance series and 20 in the lactose series plus an additional four people were tested for acetylator status. Six people in both the lactose and acetylator series turned out to be receiving outpatient therapy for pulmonary tuberculosis which included isoniazid. One other tuberculous patient was included in the lactose but not the acetylator series. Included in both series was the adenosine deaminase deficient case recently reported by Jenkins (1973). No one underwent both glucose and lactose tolerance tests. 


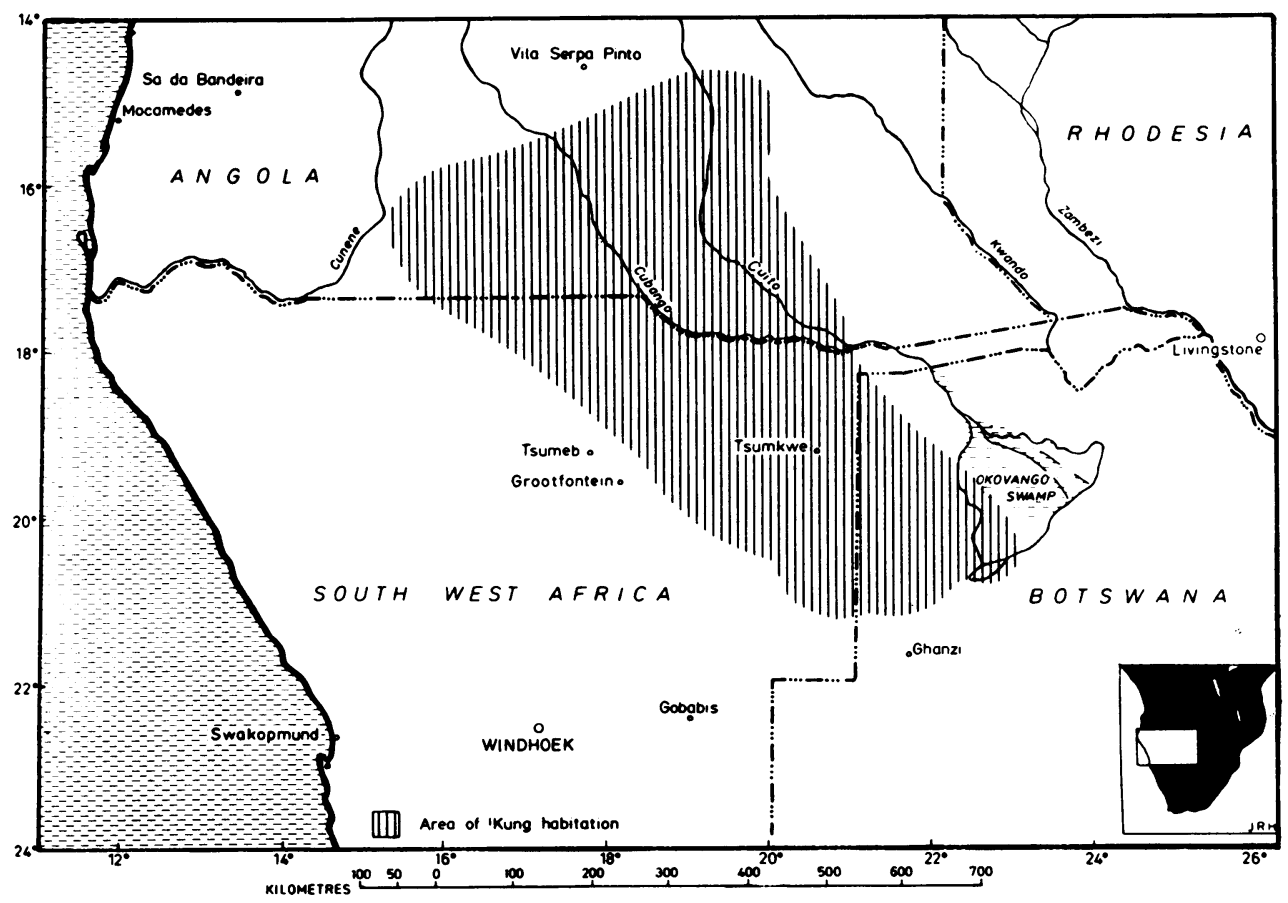

FIG. 1-Sketch map of southern Africa showing distribution of the !Kung and position of Tsumkwe.

The population around Tsumkwe consists effectively of a single hunter-gatherer group and it was to be expected that related individuals would be included in any samples of appreciable size. The lactose series included two groups of three sibs with the daughters of one sib pair, two groups of parents and one child, and one mother-daughter pair. The acetylator series included one group of three sibs, one pair of sibs, and one father-son pair.

\section{TESTS}

With the exception of a single individual who had fasted for only about five hours all tests were carried out on people who had fasted overnight. When the same people were included in two series the tests were carried out on different days.

Lactose Tolerance Tests. - The subjects were ranged in groups of five or six and $2 \mathrm{ml}$ of blood were withdrawn from each through a 1 in $(2.5 \mathrm{~cm}) 22$-gauge needle into an evacuated Venoject tube containing $4 \mathrm{mg}$ potassium oxalate and 5 $\mathrm{mg}$ sodium fluoride. After this $50 \mathrm{~g}$ of lactose in $500 \mathrm{ml}$ water was given and further 2-ml specimens taken at 15, 30 and 60 minutes. On the first day specimens were also taken at 90 and 120 minutes, but the results were not such as to justify the additional discomfort to the volunteers on subsequent days. The specimens were tested on the same day for glucose levels by the glucose oxidase method of Werner et al. (1970), using GOD-Perid kits supplied by Boehringer Mannheim.

Glucose Tolerance Tests.-The same procedure was followed for these except that specimens were withdrawn from all the subjects at 90 and 120 minutes after the administration of the $50 \mathrm{~g}$ glucose in $400 \mathrm{ml}$ water.

Acetylator Status.-To investigate acetylator status the procedure recommended by Evans (1969) was followed and crushed standard tablets of sulphadimidine were given with a drink of water to the fasting subjects-one tablet each to those below $112 \mathrm{lb}(50.8 \mathrm{~kg})$ in weight and one and a half tablets to those above that weight. The subjects remained fasting for two hours and were then given tea and toast, after which they continued fasting until six hours after taking the drug. Five hours after taking the drug they emptied their bladders and were told not to do so again for another hour. They then emptied their bladders once more and all the specimens were collected. The total volume of each was measured, each specimen mixed thoroughly, and a $20-\mathrm{ml}$ sample of each removed to a clean (new) Macartney bottle. After the specimens had been labelled and sealed they were placed in a freezer at $-20^{\circ} \mathrm{C}$ and then transported frozen and packed in ice to the unit's laboratory in Johannesburg. There they were tested for the levels of total and unconjugated sulphadimidine by the method recommended by Weiner and Lourie (1969), a slight modification of the micromethod devised by Varley (1954) from the original technique of Bratton and Marshall (1939) for the determination of sulphanilamide. The degree of acetylation was calculated by dividing the difference between total and unconjugated sulphadimidine by the total concentration.

\section{Results}

The mean levels and ranges of blood glucose at various times after administration of $50 \mathrm{~g}$ lactose are given in table $\mathrm{I}$ and the scatter of individual responses at 15 minutes is shown in fig. 2. In only one subject did the level rise by $20 \mathrm{mg} / 100 \mathrm{ml}$. Though in some individuals the level either continued to rise after 15 minutes or showed a late rise in no other instance was there a rise as high as $20 \mathrm{mg}$. The response of a single Caucasian control, known to be a milk drinker, and the mean levels in the test series are shown in fig. 3. The blood glucose levels of six individuals at intervals after taking $50 \mathrm{~g}$ lactose are shown in table II. The percentage acetylation of sulphadimidine five to six hours after ingestion is shown in fig. 4. None of the subjects showed any adverse response to lactose or sulphadimidine.

TABLE I-Mean Blood Glucose Levels after $50 \mathrm{~g}$ Lactose in a Sample of !Kung Adults

\begin{tabular}{c|c|c|c|c|c|c}
\hline \multirow{2}{*}{$\begin{array}{c}\text { Time } \\
\text { (min) }\end{array}$} & \multirow{2}{*}{$\begin{array}{c}\text { No. of } \\
\text { Subjects }\end{array}$} & \multicolumn{2}{|c|}{$\begin{array}{c}\text { Blood Glucose } \\
\text { (mg/100 ml) }\end{array}$} & Variance & S.D. & S.E. \\
\cline { 3 - 4 } & & Range & Mean & & & \\
\hline 0 & 40 & $48-75$ & 60.75 & 47.22 & 6.87 & 1.09 \\
15 & 40 & 48.80 & 61.78 & 59.26 & 7.70 & 1.22 \\
30 & 39 & $43-75$ & 61.03 & 69.29 & 8.32 & 1.33 \\
60 & 40 & $44-82$ & 62.25 & 63.99 & 8.00 & 1.26 \\
90 & 20 & $46-75$ & 62.65 & 78.45 & 8.86 & 1.98 \\
120 & 19 & $56-79$ & 63.95 & 35.27 & 5.94 & 1.36 \\
\hline
\end{tabular}




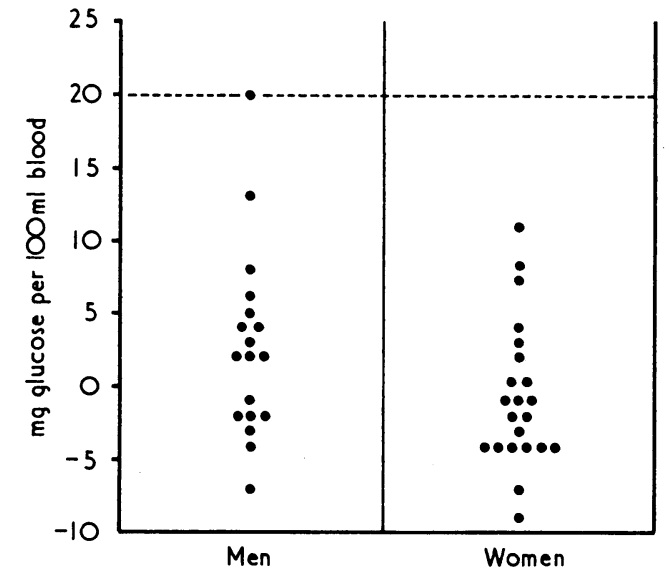

FIG. 2-Scatter of individual responses of 18 male and 22 female !Kung to $50 \mathrm{~g}$ lactose.

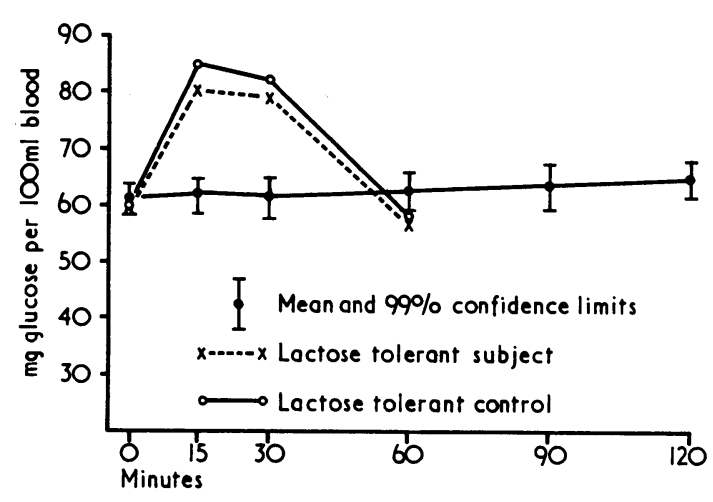

FIG. 3-Response of 39 IKung adults, one probable lactose tolerant !Kung man, and a Caucasoid control to $50 \mathrm{~g}$ lactose.

TABLE II-Blood Glucose Levels $(\mathrm{mg} / 100 \mathrm{ml})$ in Six /Kung Adults after $50 \mathrm{~g}$ Glucose

\begin{tabular}{|c|c|c|c|c|c|c|c|c|}
\hline \multirow{2}{*}{$\begin{array}{l}\text { Sub- } \\
\text { ject }\end{array}$} & \multirow[b]{2}{*}{ Sex } & \multirow{2}{*}{$\begin{array}{l}\text { Age } \\
\text { (yr) }\end{array}$} & \multicolumn{6}{|c|}{ Time (min) } \\
\hline & & & 0 & 15 & 30 & 60 & 90 & 120 \\
\hline $\begin{array}{l}1 \\
2 \\
3 \\
4 \\
5 \\
6\end{array}$ & $\begin{array}{l}\text { M. } \\
\text { M. } \\
\text { M. } \\
\text { F. } \\
\text { F. }\end{array}$ & $\begin{array}{l}52 \\
47 \\
50 \\
26 \\
22 \\
26\end{array}$ & $\begin{array}{l}46 \\
63 \\
84 \\
67 \\
59 \\
59\end{array}$ & $\begin{array}{l}61 \\
74 \\
87 \\
73 \\
94 \\
80\end{array}$ & $\begin{array}{r}95 \\
103 \\
114 \\
101 \\
102 \\
102\end{array}$ & $\begin{array}{l}131 \\
133 \\
170 \\
128 \\
138 \\
120\end{array}$ & $\begin{array}{r}107 \\
145 \\
157 \\
129 \\
98\end{array}$ & $\begin{array}{r}111 \\
102 \\
111 \\
99 \\
125 \\
66\end{array}$ \\
\hline
\end{tabular}

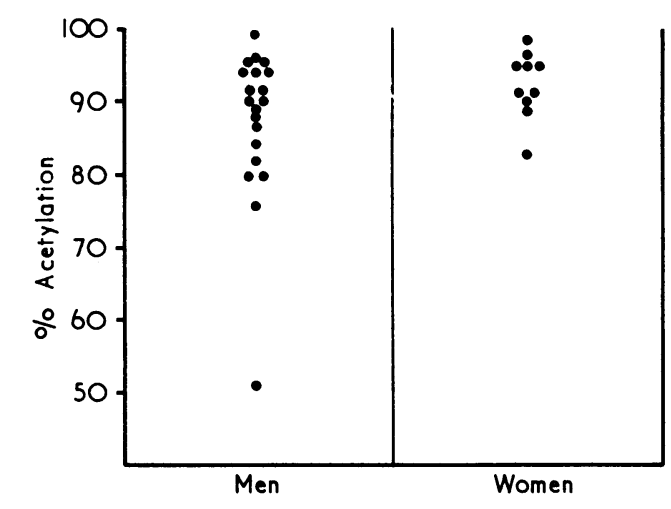

FIG. 4-Percentage acetylation of sulphadimidine five to six hours after ingestion in 20 male and 10 female IKung.

\section{Discussion}

Malabsorption of lactose by adults has been reported in a variety of ethnic groups (Cook and Kajubi, 1966; McMichael et al., 1966; Jersky and Kinsley, 1967; Gudmund-Hoyer and Jarnum, 1969; Alzate et al., 1969; Kretschmer et al., 1971) and has been shown to correlate with the use of unfermented milk as a foodstuff (Simoons, 1970; Kretschmer, 1971; Kretschmer, 1972). Simoons (1970) postulated that tolerance to lactose represents an advantageous adaptation which has arisen since the development of dairying 12,000 years ago; this has been challenged by Kretschmer (1971) who holds that too shont a period has elapsed for it to have reached its present high, albeit localized, level of prevalence. Since all babies, except those with inherited neonatal lactase deficiency (Holzel, 1968), in all populations may be supposed to have normal levels of lactase during the suckling period the gene concerned in the production of adult tolerance may be presumed to be an allele at a regulator rather than a structural locus. It seems to follow a Mendelian dominant pattern of inheritance (Bayless et al., 1969).

Milk powder is a cheap and readily available dietary supplement widely distributed to the undernourished by the wellmeaning. The vast majority of underprivileged peoples live in societies where milk traditionally is not used and they show a low prevalence of lactose tolerance. Though the San of the Kalahari do not yet show indications of being undernourished (Metz et al., 1971) they are beginning to eat purchased food stuffs, and dried milk is available to them. In our series of $\mathbf{4 0}$ adults only one man showed a rise of glucose by $20 \mathrm{mg} / 100$ $\mathrm{ml} 15$ minutes after ingestion of $50 \mathrm{~g}$ lactose, thereby attaining the lowest level at which lactose tolerance may be held to occur (Dunphy et al., 1965). In a sample this size this represented a frequency of $0.0125 \pm 0.0124$ (S.D.) for the gene controlling lactose tolerance, with a $99 \%$ probability of the number of tolerant individuals in our sample lying between 0 and 4. It therefore seems unlikely that more than $10 \%$ of the ! Kung, at the very most, are tolerant to lactose.

Though not one of the 39 intolerant individuals in our series or the 20 intolerant South African Negroes reported by Jersky and Kinsley (1967) reacted adversely to $50 \mathrm{~g}$ lactose it was by no means certain that very much larger quantities of the sugar would prove equally inoffensive. In lactose intolerance bacterial action may be expected to convent undigested lactose reaching the lower bowel into smaller molecules such as lactic and acetic acids, resulting in a high osmotic pressure and low $\mathrm{pH}$ in the colonic lumen and consequently in an acid diarrhoea. Skimmed dried milk consists of $51 \%$ carbohydrate (Latham, 1965), and most if not all of this could be expected to be lactose. There are no signs yet that the ! Kung intend to consume reconstituted dried milk by the litre but any vigourous nutritional campaign, such as might erupt at any time, could obviously pose a serious public health problem. Fermented milk (amasi or amangganga) is much relished by certain Negro peoples of Southern Africa and one of us has found it convenient and appropriate in hospital practice to use cultures from the whey of amasi to ferment reconstituted dried milk for feeding to Negro patients. The complications of feeding programmes in populations of which only a small proportion is tolerant of lactose might well be prevented by some such manoeuvre; commercially available preparations of Lactobacillus bulgaricus might be suitable.

There are indications that the San are relatively intolerant of carbohydrate. Joffe et al. (1971) tested the glucose tolerance of 15 adult ! Kung at Dobe in Botswana and found a mean rise of $74 \mathrm{mg} / 100 \mathrm{ml}$ above the fasting level after one hour compared with a mean rise of $57 \mathrm{mg} / 100 \mathrm{ml}$ in their Caucasian control series. Our six !Kung also produced a mean 60 minute rise of $73 \mathrm{mg} / 100 \mathrm{ml}$, though their mean fasting level (after an overnight fast) was $63 \mathrm{mg} / 100 \mathrm{ml}$ compared with the $95 \mathrm{mg} / 100 \mathrm{ml}$ Joffe et al. (1971) found after a fast of only four hours. After two hours Joffe's subjects had a mean level 
$26 \mathrm{mg}$ above fasting while ours were raised $39 \mathrm{mg}$ and Joffe's controls were up by only $16 \mathrm{mg}$. Since different methods were used in the estimations the absolute values are not strictly comparable but the prolonged increase after two hours in both San series certainly suggested a diabetes-like condition in the San. This could not have been a "starvation diabetes" since both our subjects and those tested by Joffe et al. had adequate food supplies. Joffe et al. (1971) suggest that the San's unusual diet may be responsible and point out that the consumption of large amounts of mannoheptulose, for example, will block insulin release (Nutrition Reviews, 1971). No information about the chemical constituents of veldkos is available so the possibility that one or more of the vegetable foods consumed may contain a substance with a similar action is certainly worth considering.

The San are well adapted to their environment. Though they are sparely built their traditional diet is of high nutritive value (Wehmeyer et al., 1969) and except during periods of prolonged shortage they do not suffer from malnutrition. The change in diet which is being brought about through the availability of processed foods will probably include increased consumption of refined sugar and its products. Schmidt-Nielsen et al. (1964) established that diabetes is induced in the North African sand-rat when it is fed on a standard balanced laboratory diet and this can be prevented only by feeding on a vegetable diet. The prosperous Indians of Natal have a far higher incidence of diabetes than the more frugal Indians of India (Campbell 1963). The possibility that the unusual glucose-tolerance curves of the San may indicate that increased consumption of sugar will induce clinically obvious diabetes in them is one not lightly to be discounted.

Only one of our subjects turned out to be a slow acetylator. $\mathrm{He}$ was a 38-vear-old man who was receiving treatment for tuberculosis. Tiitinen (1969) has shown that the administration of Sulphamezathine (sulphadimidine) along with isoniazid has no significant effect on the plasma half life of isoniazid in either fast or slow acetylators. It seems therefore that the smaller quantity of more efficient enzyme present in slow acetvlators (Weber and Cohen, 1967) is still available in sufficient amounts for there not to be competition between the substrates and that the quantity of enzyme in rapid acetylators is sufficiently great to cope adequately with the two drugs simultaneously. Furthermore, the five other people in our series who were also receiving treatment for tuberculosis were all rapid acetylators. We were therefore satisfied that the man concerned was truly a slow acetylator. Since slow acetylation is recessively inherited (Parker, 1969) we derived a gene freauency of $0.235 \pm 0.077$ (S.D.) for the condition in the San. This gave $99 \%$ confidence limits for the number of slow acetylators in our sample as between 0 and 6 . The possibility therefore exists that up to $20 \%$ of San may be slow inactivators of isoniazid.

We emphasize that these were preliminary studies and that further data which we hope to assemble may narrow the confidence limits of our prevalence estimates. In the meantime we recommend caution in the administration of lactose-containing products or of large quantities of refined sugar to the San and at least suggest that the acetylator status of individuals who react adversely to isoniazid or sulphonamides should be investigated. It is easy to administer a test dose of sulphadimidine to a fasting individual and to colleot urine at the appropriate time. Facilities for rapid freezing and for the transpont of frozen material exist almost everywhere where the San are likely to present for medical treatment and urine can easily be tested at any laboratory possessing the necessary reagents and a reliable colorimeter.

We are grateful to Professor J. H. S. Gear, director of the South African Institute for Medical Research, and Professor J. F. Murray, deputy director and chairman, school of pathology, the South African Institute for Medical Research and University of the Witwatersrand, for the facilities which enabled this study to be carried out; to Greta Wakefield, Anette Rüdiger, and Benigna Lehmann for help in the field; to Mr. J. Jonker, Bushman Commissioner, and Sister L. Coetzee of Tsumkwe for their hospitality and help; to the !Kung subjects for their willing co-operation; to the Department of Bantu Administration and Development and the South West Africa Administration for their generous permission to visit Bushmanland; and to the South African Medical Research Council for the financial assistance which made field work possible.

\section{References}

Alzate, H., Gonzalez, H., and Guzman, J. (1969). American fournal of Clinical Nutrition, 22, 122.

Bayless, T. M., Christopher, N. L., and Boyer, S. H. (1969). Fournal of

Clinical Investigation, 48, 6a.
Bayless, T. M., and Rosenweig, N. S. (1966). Fournal of the American Medical Association, 197, 968 .

Bowie, M. D., Brinkman, G. L., and Hansen, J. D. L. (1963). Lancet, 2, 550. Bratton, A. C., and Marshall, E. K. (1939). Fournal of Biological Chemistry, $128,537$.

Campbell, G. D. (1963). South African Medical fournal, 37, 1195.

Cook, G. C., and Kajubi, S. K. (1966). Lancet, 1, 525

Cuatrecasas, P., Lookwood, D. H., and Caldwell, J. R. (1965). Lancet, 1, 14

Dean, R. F. A. (1962). East African Medical Fournal, 39, 425.

Dunphy, J. V., et al. (1965). Gastroenterology, 49, 12.

Evans, D. A. P., (1962). Médecine et Hvgiène, 20, 905.

Evans, D. A. P. (1969). Fournal of Medical Genetics, 6, 405.

Gudmund-Hoyer, E., and Jarnum, S. (1969). Acta Medica Scandinavica, 186, 235.

Guerreiro, M. V. (1968). Bochimanes !Kung de Angola. Lisbon, Junta de Investigacióes do Ultramar.

Holzel, A. (1968). Proceedings of the Royal Society of Medicine, 61, 1095.

Jenkins, T. (1973). Lancet, 2, 736

Jersky, J., and Kinsley, R. H. (1967). South African Medical fournal, 41, 1194 Joffe, B. I., et al. (1971). British Medical fournal, 4, 206.

Knight, R. A., Selin, M. J., and Harris, H. W. (1959). Transactions of the 18th Conference on the Chemotherapy of Tuberculosis, p. 52. Washington, Veterans Administration Department of Medicine and Surgery.

Kretschmer, N. (1971). Gastroenterology, 61, 805.

Kretschmer, N. (1972). Scientific American, 227, 4, 70.

Kretschmer, N., Ransome-Kuti, O., Hurwitz, R., Dungy, C., and Alakija, W. (1971). Lancet, 2, 392.

Latham, M. (1965). Human Nutrition in Tropical Africa. Rome, Food and Agriculture Organization of the United Nations.

Lee, R. B. (1965). Subsistence Ecology of !Kung Bushmen. Ph.D. Thesis University of California, Berkley.

McMichael, H. B., Webb, J., and Dawson, A. M. (1966). British Medical fournal, 2, 1037.

Metz, J., Hart, D., and Harpending, H. C. (1971). American Fournal of Clinical Nutrition, 24, 229.

Nutrition Reviews. (1971). 29, 126.

Parker, J. M. (1969). Human Heredity, 19, 402.

Peters, J. H., Gordon, G. R., and Brown, P. (1965). Life Sciences, 4, 99.

Schmidt-Nielsen, K., Haines, H. B., and Hackel, D. B. (1964). Science, 143, 698.

Simoons, F. J. (1970). American fournal of Digestive Diseases, 15, 695.

Thomas, E. M. (1959). The Harmless People. London, Secker and Warburg.

Tiitinen, H. (1969). Scandinavian. Fournal of Respiratory Diseases, 50, 281.

Varley, H. (1954). Practical Clinical Biochemistry, London, Heinemann.

Weber, W. W., and Cohen, S. N. (1967). Molecular Pharmacology, 3, 266.

Weiner, J. S., and Lourie, J. A. (1969). Human Biology: a guide to field methods. Oxford, Blackwell.

Werner, W., Rey, H. G., and Wielinger, H. (1970). Zeitschrift für analytische Chemie, 252, 224.

Westphal, E. O. J., (1963). Africa, 33, 237. 